Normative Change and Security Community Disintegration 

Simon Koschut

\section{Normative Change and Security Community Disintegration}

Undoing Peace 
Simon Koschut

Otto Suhr Institute for Political Science

Freie Universität Berlin

Berlin, Germany

ISBN 978-3-319-30323-9

DOI 10.1007/978-3-319-30324-6

ISBN 978-3-319-30324-6 (eBook)

Library of Congress Control Number: 2016945042

(C) The Editor(s) (if applicable) and The Author(s) 2016

This work is subject to copyright. All rights are solely and exclusively licensed by the Publisher, whether the whole or part of the material is concerned, specifically the rights of translation, reprinting, reuse of illustrations, recitation, broadcasting, reproduction on microfilms or in any other physical way, and transmission or information storage and retrieval, electronic adaptation, computer software, or by similar or dissimilar methodology now known or hereafter developed.

The use of general descriptive names, registered names, trademarks, service marks, etc. in this publication does not imply, even in the absence of a specific statement, that such names are exempt from the relevant protective laws and regulations and therefore free for general use. The publisher, the authors and the editors are safe to assume that the advice and information in this book are believed to be true and accurate at the date of publication. Neither the publisher nor the authors or the editors give a warranty, express or implied, with respect to the material contained herein or for any errors or omissions that may have been made.

Cover illustration: (C) EdBookPhoto/Alamy Stock Photo

Printed on acid-free paper

This Palgrave Macmillan imprint is published by Springer Nature

The registered company is Springer International Publishing AG Switzerland 
To Nancy

Whose wisdom and warmth has been a continuous source of inspiration 



\section{Preface}

A community rests on the commitment of its members to intuitively follow and reproduce the social norms that are constitutive to its formation. In this sense, I agree with Heidegger (1969) who claims that the shared understanding that constitutes a community is, more often than not, 'ready-to-hand' (zubanden) instead of simply 'present-at-hand' (vorhanden). As Bauman (2001, p. 11) notes, 'we hardly ever notice the air we breathe, unless it is the foul and malodorous air of a stuffy room that we happen to inhale.' As long as this system of tacitly respected 'settled' norms is internalized by all members, the community will probably outlive almost any 'unsettling' changes in its external or domestic environment. Once members begin to question the shared meaning of their social relationship, and its underlying norms, and stop caring for each other's well-being, however, the 'air will turn foul' and the community may subsequently head down the road to disintegration.

The investigation of normative change is becoming increasingly popular in international relations (IR). Most studies, however, focus on its progressive connotation. The possibility of a weakening or even disappearance of an established peaceful normative order, by contrast, tends to be often either neglected or implicitly assumed. This book develops a theoretical and empirical argument about the disintegration of security communities and the subsequent breakdown of stable peace among nations through a process of norm degeneration. A security community is considered to be 'a group which has become integrated, where integration is defined as the attainment of a sense of community, accompanied by formal or informal institutions or practices, sufficiently strong and widespread to assure 
peaceful change among members of a group with "reasonable" certainty over a "long” period of time' (Deutsch et al. 1957).

The reasons for writing this book are twofold. First, I seek to address a theoretical problem: How can we analytically conceptualize regressive and disintegrative processes in international politics? How do these processes differ from processes of peaceful integration? Coming from a Constructivist background, I-like many of my colleagues-encountered what I have described in this book as a 'progressivist bias' in much of research on the social construction of norms and security communities. The second reason for writing this book concerns an empirical problem. I was intrigued by the upsurge of disintegrative dynamics and tendencies within the North Atlantic Treaty Organization (NATO) during and after the war in Iraq and, more recently, the European Union (EU), following the Euro crisis and the refugee crisis, respectively. These phenomena presented me with the empirical puzzle for this book: Why and how might people and states give up on their prior achievements in terms of peaceful integration? What keeps such security communities together and, more importantly, what drives them apart?

To address these questions, this book draws together two key bodies of contemporary IR literature-norms and security communities-and brings their combined insights to bear on the empirical phenomenon of disintegration. The book advances the contemporary body of research on the important role of norms and ideas by analytically extending recent Constructivist arguments about international norm degeneration to the regional level and by applying them to a particular type of regional order (a security community) in order to explain the latter's demise. In contrast to widespread beliefs in both academia and policy circles that the process of peaceful regional integration is (more or less) linear and irreversible, the empirical observations presented in this book show that the members of a security community can themselves easily undo peace among them.

This book is the result of a long journey, both literally and metaphorically speaking, and I am grateful to a great number of people who offered their guidance, encouragement, and company in developing this project. When I first started thinking about the idea for this book right after completing my $\mathrm{PhD}$, I was fortunate enough to work as a visiting lecturer at the John F. Kennedy Institute at the Freie Universität Berlin. I am pleased to have the opportunity to acknowledge the help and goodwill of a splendid group of scholars whom I was privileged to have worked with there. 
A first draft of the theory chapter and the introduction were written while I was a Fritz Thyssen Fellow at the Weatherhead Center for International Affairs (WCFIA) at Harvard University. Beth Simmons, then the director of the Center, and Karl Kaiser, then the director of the Program on Transatlantic Relations, were truly caring academic supporters during my stay at the WCFIA, and so have been many others, including Stephen Walt, Alastair Iain Johnston, Felix Heiduk, Ulrich Krotz, Ronja Kempin, Steven Bloomfield, Michelle Eureka, Megan Margulies, Thomas Murphy, and Ann Townes. Max Büge, with whom I was lucky enough to share an office at the WCFIA, was the best office mate one could imagine, and I trust that he knows how much so. Spending the whole year writing is a great luxury, and I gratefully acknowledge the Fritz Thyssen Stiftung's financial support to enable me to focus on my research in such an inspiring and highly welcoming academic environment.

At the Friedrich Alexander University (FAU) at Erlangen-Nürnberg, I developed my case studies and wrote the conclusion of the book. For four years, the FAU provided me with an academic home (and a stunning view from my office, overlooking the castle and the old town). Here, I was able to work with an equally inspiring and cordial crowd of people. Andreas Falke, then my boss and mentor, provided me with generous free space to develop new ideas and to continue writing. I feel lucky and honored to have been able to work under his chairmanship during these years. Sarah Beringer was my colleague and 'partner in crime' at the chair, and I am grateful for her wisdom and cheerful laughs. Also, I would like to thank my dear colleague and running mate, Gian Luca Gardini, as well as Christina Stolte, who have both been a constant source of support and sympathy. Special thanks go to Sören Brinkmann, Wolfgang Ramsteck, Matthias Fifka, Günther Ammon, Nelia Miguel Müller, Rüdiger Zoller, Walther Bernecker, Dirk Holtbrügge, and Christoph Schumann. Even though they have not read or directly commented on this manuscript, I feel that a series of frequently spirited discussions over the past years has greatly helped to sharpen and strengthen the project. Finally, I have to thank my students at the FAU for their enduring enthusiasm and curiosity.

This book is also my Habilitationsschrift. Hence, I would like to extend my sincere gratitude to the University of Potsdam, where I submitted my Habilitation, as well as to my board of reviewers, Andrea Liese, Anja Jetschke, and Heinz Kleger. More than anyone else, Kleger, who was also my Doktorvater, taught me to think beyond disciplinary boundaries. He is 
a model of scholarly integrity and open-mindedness and I could not have wished for a better teacher.

Ironically, this book's journey ends where it began. As I am writing these lines, I have returned to the Freie Universität Berlin, this time joining the Otto Suhr Institute for Political Science as a visiting professor. I feel very privileged and honored to be working with such a superb group of scholars here, and I am pleased to thank Tanja Börzel and Thomas Risse for granting me this valuable opportunity.

Beyond those names above, a heterogeneous collection of friends and colleagues, in one way or another, contributed to this book, commenting on parts of the manuscript, offering their own knowledge and expertise, or helping in a variety of other ways. My parents, Wolfgang and Ursula Koschut, as well as my brother David, have been a neverending source of encouragement and so have been my 'American parents', Cathy and David Annas. Sarah Roughley, my editor at Palgrave, deserves praise and respect for her friendly patience and professional support. Lucile Eznack, Regina Heller, Stephan Stetter, Stephen Aris, Andreas Wenger, Simon Hollis, Matthias Dembinski, and Andrea Oelsner as well as the anonymous reviewers have pushed me to think harder and provided valuable comments that helped to prepare the final draft.

My greatest debt is to my family: my children Enja and Elio, and most importantly Nancy. Her continuing generosity and emotional support in challenging times and during my frequent absences from home deserve my unconditional love and gratitude. This book is dedicated to her.

Simon Koschut Berlin, Germany

\section{REFERENCES}

Heidegger, M. (1969). On time and being. Chicago: University of Chicago Press. Bauman, Z. (2001). Community: Seeking Safety in an Insecure World. Cambridge: Polity Press. 


\section{Contents}

1 Introduction 1

2 Security Community Disintegration:

An Analytical Framework

3 'Successful' Disintegration: The German Security Community

4 'Unsuccessful' Disintegration: The Transatlantic Security Community

5 Conclusions

References

Index 



\section{List of AbBreviations}

AfD

ASEAN

AWACS

CIA

CJTF

CSCE

EC

ECOWAS

EPC

ESDI

EU

FPÖ

ICC

IFF

KFOR

KLA

MERCOSUR

NACC

NAFTA

NATO

NSA

OSCE

PDD

PfP

SACEUR

SADC
Alternative für Deutschland/Alternative for Germany Association of Southeast Asian Nations Airborne Early Warning and Control System Central Intelligence Agency Combined Joint Task Force Conference on Security and Cooperation in Europe European Community Economic Community of West African States European Political Cooperation European Security and Defence Identity European Union Freiheitliche Partei Österreichs/Freedom Party of Austria International Criminal Court Identification Friend or Foe Kosovo Force Kosovo Liberation Army Mercado Común del Sur/Southern Common Market North Atlantic Cooperation Council North American Free Trade Agreement North Atlantic Treaty Organization National Security Agency Organization for Security and Cooperation in Europe Presidential Decision Directive Partnership for Peace Supreme Allied Commander Europe Southern African Development Community 
xiv LIST OF ABBREVIATIONS

SEATO Southeast Asian Treaty Organization

UN

United Nations

UNOSOM

United Nations Operation in Somalia

UNPROFOR

United Nations Protection Force

USA

United States of America

VOPP

Vance-Owen Peace Plan

WEU

Western European Union 


\section{List of Figures}

Fig. 2.1 The disintegration of security communities 



\section{List OF TABLES}

Table 2.1 Normative order of a security community 